\section{Etiología viral en la neumonía adquirida en la comunidad}

\author{
MAURICIO RUIZ CARMONA
}

\section{Viral etiology in community-acquired pneumonia}

Departamento de Medicina Norte. Universidad de Chile. Santiago, Chile.

Correspondencia a:

Dr. Mauricio Ruiz

Sección de Enfermedades Respiratorias, Hospital Clínico Universidad de Chile. mruiz@hcuch.cl
$\mathrm{E}$ n nuestro país la Neumonía adquirida en la comunidad (NAC) es la principal causa de mortalidad de origen infeccioso y la séptima causa específica de muerte, con una tasa de mortalidad de 18 casos por 100.000 habitantes ${ }^{1}$. Dentro de los factores modificables que pueden reducir esta mortalidad esta el elaborar terapias antimicrobianas empíricas adecuadas, las que solo pueden ser desarrolladas con información local que explore la etiología de la NAC, por esto que el artículo que publica el Dr. Saldías y colaboradores en el presente número es clave ya que aplicando técnicas moleculares de reacción en cadena de la polimerasa en tiempo real, demostraron un aumento significativo en el rendimiento diagnostico y que este aumento fue principalmente a expensas de la identificación de material genético de origen viral ${ }^{2}$. Este hallazgo ha sido ratificado en diversas latitudes: por ejemplo Burk y colaboradores publicaron un metaanalisis que incluyó 31 artículos sobre etiología viral de la NAC y que contabilizó un total de 10.762 pacientes $^{3}$, y que tomados en conjunto, los virus contribuyeron en un $24,5 \%$ (95\% CI $21,5-27,5 \%)$ a la etiología de la NAC y cuando se incluyeron estudios que preferentemente recolectaron muestras de las vía respiratorias inferiores su frecuencia llegó hasta el $44,2 \%$ (95\% CI 35,1-53,3\%). Pero ¿cuál es la relevancia de estos hallazgos y de qué manera pueden influir en la toma de decisiones en el manejo de la NAC? Para intentar responder esta interrogante debemos considerar: 1) ¿La determinación rutinaria de material genético viral es costo efectiva? La evidencia es poco clara, por un lado diversos estudios han señalado una reducción en los días de estancia hospitalaria ${ }^{4}$, pero en contraste esos mismos estudios no pudieron demostrar una reducción en la prescripción de antibióticos, ni en la duración de los tratamientos de modo que el beneficio final queda en duda; 2) ¿La identificación de un agente viral en la NAC tiene significado pronóstico? La mayoría de los estudios no han demostrado que la NAC de origen viral tenga un impacto significativo en la mortalidad, incluso si solo se analiza el subgrupo de NAC grave que requieren su ingreso a la Unidad de Cuidados Intensivos $^{3,5}$. No obstante, una importante proporción de las NAC de origen viral son en realidad coinfecciones que en adulto va entre un $4 \%$ hasta un $30 \%$ de las series publicadas ${ }^{6}$. Los mecanismos patogénicos involucrados posiblemente incluyan el daño epitelial y alteraciones en la inmunidad Innata que permiten un aumento en la expresión de receptores para diversas bacterias ${ }^{7}$. En este subgrupo de pacientes la evidencia sugiere que la coinfeccion bacteriana/viral, podría tener mayor morbilidad $^{3}$ y mortalidad ${ }^{2,7}$, en consecuencia estas nuevas técnicas moleculares permitirían una rápida identificación de pacientes con coinfeccion y por ende una mayor vigilancia clínica para reducir la posibilidad de complicaciones, este aspecto no ha sido aun explorado en estudios prospectivos; 3) ¿La identificación de material genético viral tiene impacto en las políticas de salud? Este aspecto es, en mi opinión, el más relevante ya que la posibilidad de obtener un diagnostico precoz de infecciones potencialmente transmisibles en el ámbito hospitalario, es esencial en los esfuerzos para controlar su propagación. Este beneficio ha sido más evidente en unidades pediátricas ${ }^{4}$. Desde la perspectiva de la salud publica la determinación del perfil de virus causantes de NAC y su comportamiento estacional es fundamental para el desarrollo de políticas públicas que enfrenten 
esta contingencia y que reconozcan precozmente la aparición de brotes epidémicos; 4) ¿Qué proyecciones tiene la constatación de que los virus son importantes agentes en la NAC? A mi juicio la importancia de los virus en la etiología de la NAC, ha dado nuevos bríos a la comunidad científica para la búsqueda de nuevos antivirales sobretodo para el tratamiento del Rhinovirus, Virus Respiratorio Sincicial y Metaneumovirus y al desarrollo de nuevos antivirales para el tratamiento de la Influenza. Así mismo se están investigando vacunas para prevenir infecciones virales y anticuerpos monoclonales que bloqueen la unión del virus con su receptor en la célula huésped ${ }^{6}$.

En suma podemos decir que hay un creciente número de evidencia que apunta que los virus son agentes importantes en la NAC del adulto y que su relevancia a nivel individual y colectivo requiere de una mayor información proveniente de investigaciones prospectivas bien diseñadas.

\section{Referencias}

1. Programa de Infecciones Respiratorias Agudas (IRA), Departamento de Estadísticas e Información de Salud, Ministerio de Salud de Chile, 2016.
2. Saldías F, Ortega M, Fuentes G, Elola JM, Uribe J, Morales A, et al. Participación de los virus respiratorios en la neumonía del adulto inmunocompetente adquirida en la comunidad. Rev Med Chile 2016; 144: 1513-22.

3. Burk M, El-Kersh K, Saad M, Wiemken T, Ramirez J, Cavallazzi R. Viral infection in community-acquired pneumonia: a systematic review and meta-analysis. Eur Respir Rev 2016; 25: 178-88.

4. Vallières E, Renaud Ch. Clinical and economic impact of multiplex respiratory virus assays. Diagnostic Microbiology and Infectious disease 2013; 76: 255-61.

5. Choi SH, Hong SB, KO GB, Lee Y, Park HJ, Park SY, et al. Viral infection in patients with severe pneumonia requiring intensive care unit admission. Am J Respir Crit Care Med 2012; 186 (4): 325-32.

6. Pavia AT. What is the role of respiratory viruses in Community-Acquired Pneumonia? What is the best therapy for influenza and other viral causes of Community-Acquired Pneumonia?. Infect Dis Clin N Am 2013; 27: 157-75.

7. Chertow DS, Memoli MJ. Bacterial coinfection in influenza grand rounds review. JAMA 2013; 309 (3): 275-82.

8. Johansson N, Kalin M, Tiveljung-Lindell A, Giske CG, Hedlund J. Etiology of Community-Acquired Pneumonia: Increased microbiological yield with new diagnostic methods. Clinical Infectious Diseases 2010; 50: 202-9. 